\title{
Article \\ Improving Mudstone Materials in Badland in Southwestern Taiwan by Increasing Density and Low-Cement Amount
}

\author{
Darnhorng Hsiao *(D) and Chiasheng Hsieh (D) \\ Department of Civil Engineering, National Kaohsiung University of Science and Technology, \\ 415 Chien Kung Road, Kaohsiung 80778, Taiwan; hsieh@nkust.edu.tw \\ * Correspondence: hsiaodh@nkust.edu.tw; Tel.: +88-673-814-526 (ext. 15259)
}

check for

updates

Citation: Hsiao, D.; Hsieh, C.

Improving Mudstone Materials in

Badland in Southwestern Taiwan by Increasing Density and Low-Cement Amount. Appl. Sci. 2022, 12, 2290. https://doi.org/10.3390/ app12052290

Academic Editors: Małgorzata Jastrzębska, Krystyna KazimierowiczFrankowska, Gabriele Chiaro and Jaroslaw Rybak

Received: 18 January 2022

Accepted: 20 February 2022

Published: 22 February 2022

Publisher's Note: MDPI stays neutral with regard to jurisdictional claims in published maps and institutional affiliations.

Copyright: (C) 2022 by the authors. Licensee MDPI, Basel, Switzerland. This article is an open access article distributed under the terms and conditions of the Creative Commons Attribution (CC BY) license (https:// creativecommons.org/licenses/by/ $4.0 /)$.

\begin{abstract}
The southwestern foothills in Taiwan contain abundant mudstone, which softens or slakes easily when contacting water. Thereafter, this condition causes high rates of erosion during heavy rain, eventually leading to the formation of badlands. To increase land use value in Taiwan, this study aimed to offer a new solution with the use of compaction techniques and also adding a small amount of cement as soil amendment. We examined the feasibility of this concept by performing a series of tests, including the basic physical property test, compaction test, unconfined compression test, static triaxial CU and UU tests, consolidation test, California bearing ratio (CBR) test, and triaxial permeability test. The specimens were created based on the controlled moisture at the wet side along the compaction curve. Three clods, three preparation methods, and two types of cement content were used for specimen preparation. The test results revealed that clod will affect the results of unconfined compression strength and soil permeability. For mudstone with added cement, its unconfined compression strength increased 7- to 10-fold and its shear strength increased 2- to 3-fold. The results of consolidation and the CBR test showed that improvement is possible by using low amounts of cement. Overall, the present method not only adheres to low-carbon and environmental protection requirements, but also verifies the feasibility of using compacted mudstone as an engineering material.
\end{abstract}

Keywords: Taiwan mudstone; engineering compaction; cement paste; engineering material improvement

\section{Introduction}

The southwestern foothills of Taiwan contain an abundance of mudstone. The local mudstone softens or slakes easier when it is soaked with water, so mudstone material is rarely developed. However, Taiwan is a densely populated small island, where the usage of its plain area is extremely limited. In recent years, oil storage tanks had to be moved to or constructed in mudstone areas, while reservoirs, landfills, industrial areas, and universities were also established in mudstone areas. Thus, the engineering properties of crushed mudstone need to be investigated beforehand. Studies have shown that mudstone is silt/clay sedimentary rock that lacks lamination or fissility, while durability may be its most crucial engineering property. When discussing a major cause of landslides in mudstone, Goodman [1] discussed environments with severe weathering effects. In Taiwan, mudstone is mainly distributed across the southwestern foothills, specifically the southern section of the Coastal Mountain Range of Eastern Taiwan and in Kenting, which is located in the Hengchun Peninsula. Exposed mudstone is most abundant in the southwestern foothills that span the area from Chiayi to Kaohsiung (Figure 1a). Figure 1b shows the mudstone environment along the sides of the northern exit of Chungliao Tunnel in the Second National Expressway of Taiwan. In total, the mudstone stratum area in Taiwan exceeds $1000 \mathrm{~km}^{2}$. When it comes to a major cause of landslides in mudstone-distributed areas, environments with severe weathering effects are a key factor according to Goodman [1]. Under dry conditions, boring tunnels through mudstone is extremely difficult. When moisture content 
increases, mudstone strength decreases, thereby resulting in engineering disasters [2]. Lee et al. stated [3-5] that dry mudstone exhibits high strength; however, the strength of mudstone that has absorbed an excessive volume of water is substantially lower. This is because when water infiltrates mudstone, the diagenetic bonds between mudstone grains are gradually destroyed. When these bonds are destroyed, the recoverable strain energy stored in the compressed and deformed mudstone grains is released. Partial mudstone swells [3-5]. A study explored the bedrock characteristics of Plio-Pleistocene mudstone slopes in southwestern Taiwan and their effects on hydraulic and geophysical processes; the researchers used pore-water chemistry to demonstrate that mudstone causes high rates of erosion during heavy precipitation periods in Taiwan and, consequently, the formation of badlands [6].

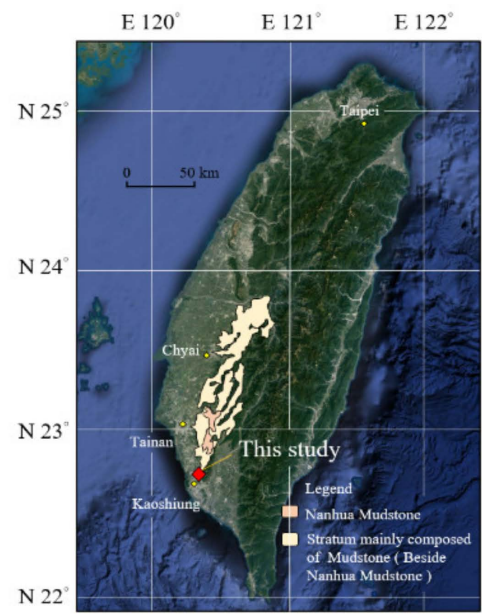

(a)

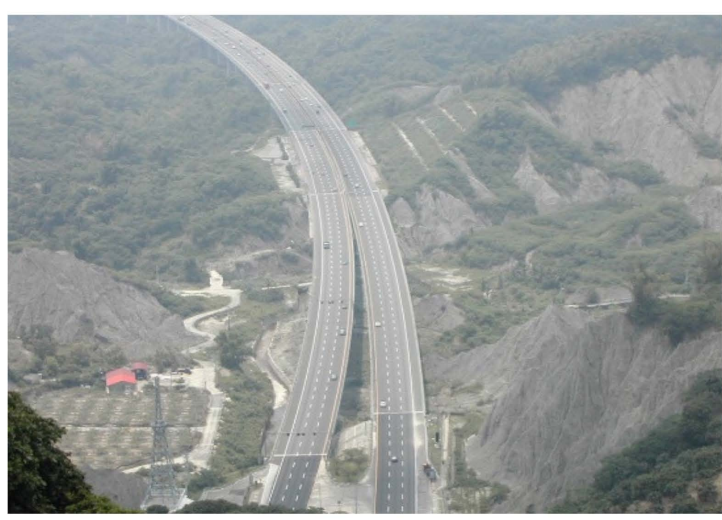

(b)

Figure 1. Distribution areas and bird view picture of mudstone in Taiwan: (a) The outcrops locations of mudstone (redrawn from Wang and Huang (2002)); (b) The famous badland slope situated along the northern exit of Chungliao Tunnel.

Numerous methods have been utilized to strengthen soil bearing capacity, including piling or soil improvement. For instance, Zhao and Zhao [7] applied construction waste in the reinforcement of soft soil foundation with cementation materials in coastal cities. Cementation was also used in some on-site soil improvement projects [8-12], in which the effect of waste or waste liquid on clay engineering properties was tested $[13,14]$. In laboratory research, Portland cement was added to improve clay and the remolded specimens were created for unconfined compression tests. The specimen curing duration can be 1 day, 7 days, 28 days, 56 days, or 90 days. The test results revealed that an increase in the curing period is associated with an increase in unconfined compression strength. Similar tests were conducted to achieve soil improvement by using pozzolanic reaction materials such as fly ash, lime, and furnace slag [15-22]. Epoxy was also added in soil specimens to facilitate the performance of triaxial compression tests; the test results revealed that the compression strength, tensile strength, and elastic modulus increased with curing period and decreased with an increase in moisture content based on the study of Anagnostopoulos et al. [23]. Research on low cement use involves the addition of cement and sewage sludge ash to reinforce the weak soil. In these studies, the proportion of cement added could be $0 \%, 2 \%, 4 \%$, $8 \%$, or $16 \%$. The results of compaction tests indicated that when $2-8 \%$ cement was added on the dry side, maximum dry density increased with cement paste content. When the cement paste content reached $16 \%$, dry density decreased. In addition, similar tendencies were observed on the wet side. Consoli et al. [16] described experiments involved the addition of cement $(1 \%, 2 \%, 3 \%, 5 \%$, and $7 \%)$ and a moisture content of $10 \%$ [16]. Another study involved the addition of cement $(2 \%, 9 \%$, and $12 \%)$ and the application of varying moisture content levels $(4 \%, 6 \%, 8 \%, 12 \%$, and $13.4 \%)$ to conduct a series of tests aimed at investi- 
gating the effectiveness of cement paste addition [24]. Preetham and Nayak [22] added granulated blast furnace slag (GBFS) and cement to the soil to investigate the geotechnical properties of mixtures, including physical properties, compaction characteristics, unconfined compression strength, and Unconsolidated Undrained (UU) triaxial compression test results [22]. Studies have focused on the strength related to hydraulic conductivity; Wu et al. [25] discussed that hydraulic conductivity could increase the uniformness of settlement and long-term safety showing the importance of hydraulic conductivity [25]. Wu et al. [26] also used cement to improve weak marine clay and found that strength is influenced by cement- and density-related factors. This indicates that the effect of density on strength is comparable to that of cement [26]. On the other hand, the moisture content used for preparing specimens applied in unconfined compression and triaxial compression tests affects results substantially. Several studies have applied high moisture content during specimens' preparation $[20,27,28]$. Ge et al. [28] applied moisture content levels of 1.8-, 2.0-, and 2.2-fold the liquid limit (LL) of kaolinite to prepare specimens [28]. Another study applied low moisture content to prepare specimens that primarily comprised ordinary Portland cement (OPC) and local lithomargic clay collected in the Dakshina Kannada district of India. In the study, clay was dried at $105^{\circ} \mathrm{C}$ then screened and mixed by weight with varying proportions of cement $(2.5 \%, 5 \%, 7.5 \%$, and $10 \%)$. Water was added according to optimum moisture content (OMC). Thereafter, the obtained soil was put into a bag for curing for a given numbers of days before the specimen was removed for subsequent tests [29]. Similar methods were also proposed in other studies [15,16,22,30]. When we take practicality and on-site conditions into consideration, clay clods substantially affect engineering construction [24,31]. Soil gradation and the coefficient of uniformity $\left(C_{u}\right)$ both affect soil static strength [32]. Furthermore, OMC percentage and the wet side of compaction tests can be adopted when hydraulic conductivity and the strength of compacted clay are taken into account [33]. Soil saturation also affects strength [34,35]. Thus, we applied multiple preparation methods, soil gradations, and dry density levels to prepare untreated samples in the study. Varying amounts of cement paste were added into samples subjected to compaction test treatment to increase the generalizability of the study. The relationships between elastic modulus and unconfined compression strength were discussed in many studies, with $\mathrm{E}_{50}$ recommended as the elastic modulus [19,26,33,36]. Jamsawang et al. [19] and $\mathrm{Wu}$ et al. [26] investigated and discussed the relationship between $\mathrm{E}_{50}$ and $\mathrm{q}_{\mathrm{u}}$, with favorable outcomes reported $[19,26]$. The present study used compression tests to clarify the relationship between elastic modulus and compression strength. The triaxial test included confined undrained (CU) and UU tests. Specimens used for the CU test were saturated and regarded as soaked samples, whereas those used for the UU test were unsaturated and regarded as unsoaked samples. The compression test only determined the soil strength $\mathrm{q}_{\mathrm{u}}$ value. Soil shear strength parameters consisted of the $\mathrm{c}$ value and $\phi$ angle. According to the Mohr-Coulomb theory, soil shear strength is calculated using the Equation (1).

$$
\tau_{\mathrm{f}}=\mathrm{c}+\sigma \tan \phi,
$$

where $\tau_{\mathrm{f}}$ is shear strength, $\sigma$ is normal stress, and $\mathrm{c}$ and $\phi$ represent cohesion value angle and internal friction angle, respectively. The swelling of soil can be assessed by identifying the effect of infiltration saturation and vertical stress on GMZ bentonite swelling indicated by Chen et al. [37]. The present study adopted the California bearing ratio (CBR) test. As clay, which is rich in smectite, possesses a high swelling potential and a low hydraulic conductivity, it is commonly used as a liner for landfills. The hydraulic conductivity of clay causes desiccation cracking and adverse effects. Therefore, one-dimensional swelling deformation apparatus introduced by Emmanuel and Anggraini [38] can be used as a research instrument. Swelling can also be determined through the soaking process of the CBR test $[24,30]$. The results of related studies indicate volume swelling. Clay clods and desiccation cracks also affect the mechanisms of hydraulic conductivity $[18,29,31,39-42]$. We used the indoor permeability test to clarify the hydraulic conductivity mechanism, while consolidation and compression were also intensively studied. Since the void/cement ratio 
is considered as a main factor that contributes to the strength and compression, clay-based lightweight aggregate concrete improved with cement addition $[43,44]$.

In summary, (1) for the application of compaction test results, the moisture content of the specimens prepared in the present study was similar to the OMC level on the wet side; (2) soil strength was compared based on the CU and UU test results of the unconfined compression and triaxial compression tests, and the Mohr-Coulomb shear strength formula was used to determine the difference between mudstone and mudstone-cement samples; (3) after the compression test was completed, stress-strain curves were used to determine $\mathrm{E}_{50}$, and the relationship between elastic modulus $\mathrm{E}_{50}$ and unconfined compression strength $\mathrm{q}_{\mathrm{u}}$ was clarified; (4) the indoor permeability test was used to explore the factors related to on-site clods that could affect mudstone hydraulic conductivity; (5) the one-dimension consolidation test was used to explore the compression variation of mudstone before and after the addition of cement paste; and (6) the CBR test was used to clarify the swelling of mudstone after compaction and soaking.

\section{Materials and Methods}

\subsection{Materials}

Mudstone was collected from the Renwu district of Taiwan (Figure 1a). The district is located at the southernmost region of Taiwan where exposed mudstone can be found. Mudstone was obtained using excavators, with irrelevant on-site tree branches and stones removed. Mudstone was transported to the laboratory by trucks. The mudstone was soaked in water for days to allow for impurities to float to the water surface. Most of the water was poured out to facilitate air drying. The mudstone formed clods of various sizes, which were packed for future use. The chemical composition of mudstone from southwestern Taiwan is as follows: $\mathrm{SiO}_{2}(63.49 \%), \mathrm{Al}_{2} \mathrm{O}_{3} \cdot \mathrm{Fe}_{2} \mathrm{O}_{3}(21.53 \%)$, and $\mathrm{CaO}(2.71 \%)$. According to Lee et al. (1996) and Lee et al. (2007), an X-ray scan of mudstone in Taiwan revealed the main mineral composition as follows: illite (35.4\%), chlorite $(28.70 \%)$, and quartz $(28.45 \%)$. The secondary mineral composition of mudstone is as follows: feldspar, calcite, and kaolinite. The grain particle size distribution of weathered mudstone indicated that the silt-sized, clay-sized, and sand-sized particles accounted for $49 \%, 29 \%$, and $22 \%$, respectively, of the mudstone. OPC (type I) was purchased from Taiwan Cement Corporation and the basic chemical composition comprised $\mathrm{SiO}_{2}(21.24 \%), \mathrm{Al}_{2} \mathrm{O}_{3}(4.44 \%), \mathrm{Fe}_{2} \mathrm{O}_{3}(3.44 \%), \mathrm{CaO}(64.51 \%), \mathrm{MgO}$ $(2.35 \%)$, and $\mathrm{SO}_{3}(2.10 \%)$. The fine modulus was $349 \mathrm{~m}^{2} / \mathrm{kg}$ and the specific gravity $\mathrm{G}_{\mathrm{s}}$ was 3.16. The initial and final setting times were 139 and $255 \mathrm{~min}$, respectively, which is finished by the Vicat Needle method according to ASTM-C191-08 (2008).

\subsection{Testing Methods}

To explore the mechanical behavior of mudstone clods in which dry cement is added after compaction improvement, the present study conducted basic physical property, compaction, unconfined compression, triaxial compression, triaxial permeability, onedimension consolidation, and CBR tests with the addition of $0 \%, 4 \%$, and $8 \%$ of cement. The relevant regulations that are applied for the tests are as follows: ASTM D422 for grain size distribution curve [45]; ASTM D854 for $\mathrm{G}_{\mathrm{S}}$ (specific gravity test) [45]; ASTM D423, D424, and D4318 for Atterberg limits [45]; ASTM D2487 for USCS [45]; ASTM D2166 for the unconfined compression test [45]; ASTM D4767 for the triaxial CU compression test [45]; ASTM D2850 for the triaxial UU compression test [45]; ASTM D2216 for soil moisture content [45]; ASTM D698 and ASTM D1557 for the Proctor compaction test [45]; ASTM D2434 for the indoor permeability test [45]; ASTM D2435 for one-dimension consolidation test [45]; and ASTM D1883 and ASTM D4429 for the CBR test [45].

\subsection{Specimen Preparation}

In 2007, Consoli et al. [16] discussed specimen preparation methods. On the basis of that study, the present study prepared specimens for unconfined and triaxial compression tests. Mudstone-cement samples were prepared by weighing soil and cement as per prior 
protocols before uniformization. The present study used cement content $C$ (expressed in weight percentage) by referencing previous studies $[16,24]$, with percentage levels of $0 \%$, $4 \%$, and $8 \%$ selected. The specimens were divided into three layers and placed in cylindrical copper split molds, layer by layer. Each layer was designed based on calculations. The final layer was slightly higher than the mold height. After the preparations were complete, the specimens were demolded. The specimens were $5 \mathrm{~cm}$ in diameter and $10 \mathrm{~cm}$ in height. Subsequently, the specimens were placed in wet rooms for curing and soaked in water tanks for $24 \mathrm{~h}$ to achieve saturation and minimize suction. The total curing time ranged from 7 to 28 days, with water temperature controlled at $25^{\circ} \mathrm{C}$. Before the tests were conducted, the specimens were removed from the water tank and the surface was dried with a water-absorbing cloth. Next, unconfined compression tests were conducted and the peak load of the specimens was recorded. The present study explored the effects of different compression methods on on-site civil engineering. Three methods, namely static, compaction, and kneading, were applied (Figure 2) to prepare the specimens. The mudstone soil specimens (without cement paste) were prepared using static, compaction, and kneading methods. This factor was used to facilitate extensive exploration. The compaction method was adopted for compaction tests and CBR tests. For the application of the compaction method, tests are required to determine how preset density can be achieved. Several studies have used the static method for specimen preparation, particularly the three-layer layered static method [16,30]. Studies have also used the kneading method for specimen preparation [19,46]. The kneading method was based on the JGS T821-1990 standard, and it can be difficult to implement for specimen preparation because prior tests are required to obtain the required density. Studies have used clods or soil gradation to investigate the hydraulic conductivity of clay [31,41] and identify the effect of clods on soil engineering characteristics $[17,32,47]$. On-site experience indicates that compression often leads to varying grain sizes. In contrast to laboratory-based research, massive on-site earthworks cannot be sifted by using just one sieve with a specific opening size. Thus, soil samples that passed through sieves that were size <\#4 $(4.75 \mathrm{~mm}), \# 4-3 / 4^{\prime \prime}(19.05 \mathrm{~mm})$, or larger than $3 / 4^{\prime \prime}$ were used in further analyses. Figure 3 indicates that before unconfined compression tests were conducted using specimens from the three soil gradations, the specimens were removed, photographed, and subsequently destroyed. Specimens with added cement were prepared using the static method.

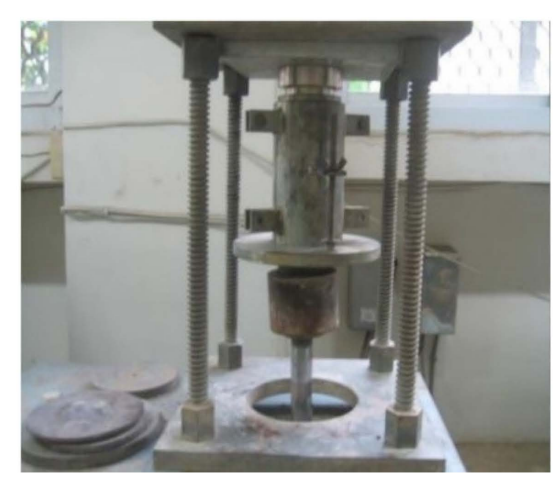

(a)

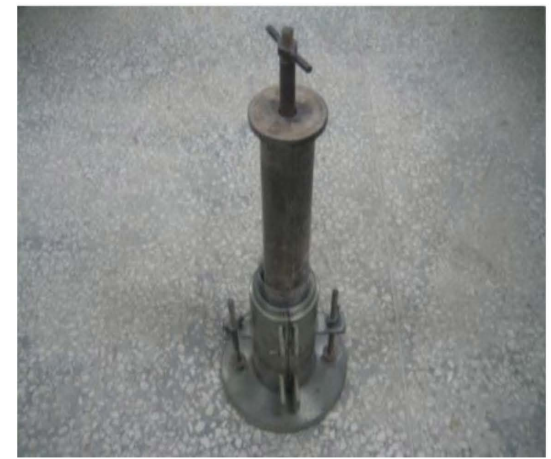

(b)

Figure 2. Cont. 


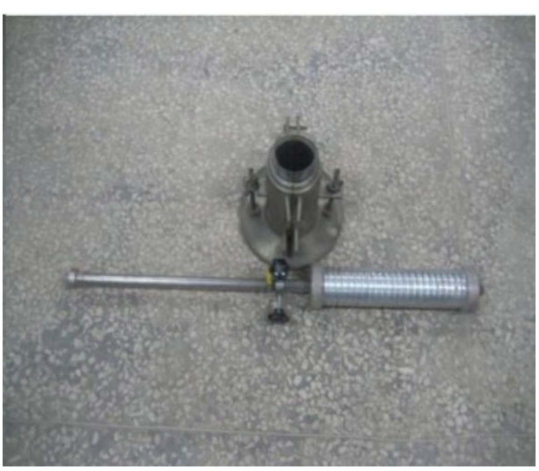

(c)

Figure 2. Three types of testing equipment for preparing soil samples: (a) static; (b) compaction; (c) kneading.

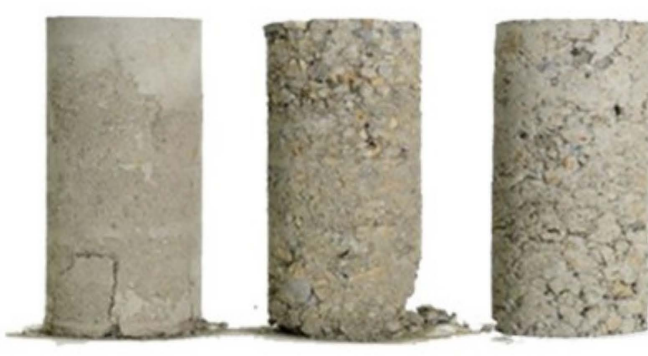

(a)
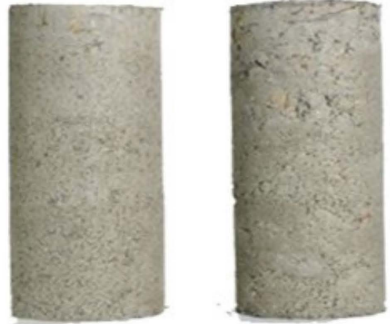

(b)

Figure 3. Sample appearance before failure: (a) compaction, kneading, and static (from left to right); (b) soil particles $<\# 4, \# 4-3 / 4^{\prime \prime}$, and $>3 / 4$ " (from left to right).

\section{Testing Results and Analysis}

\subsection{Basic Physical Properties}

The two particle size distribution curves of mudstone used in the present study are shown in Figure 4. One curve presents the relationship between the sieve analysis test curves and specific gravity test curves of the original mudstone soil that was not screened for particle size. Another curve relates to the soil samples that were passed through \#4 sieves and underwent specific gravity testing before undergoing the sieve analysis test. Figure 4 indicates that approximately $77.8 \%$ of the original soil passed through the \#4 sieve. The results of the basic soil physical property test revealed that the specific gravity of the grains was approximately 2.71. In addition to partial large grains, the grains were composed of sand-sized particles (approximately 27.3\%), silt-sized particles (approximately $31.0 \%$ ), and clay-size particles (approximately 19.5\%). The Atterberg test results revealed that the LL, PL, and plasticity index of the soil was $26.8 \%, 18.1 \%$, and $8.7 \%$, respectively. As per the USCS, the original soil was classified as CL in Figure 5. 


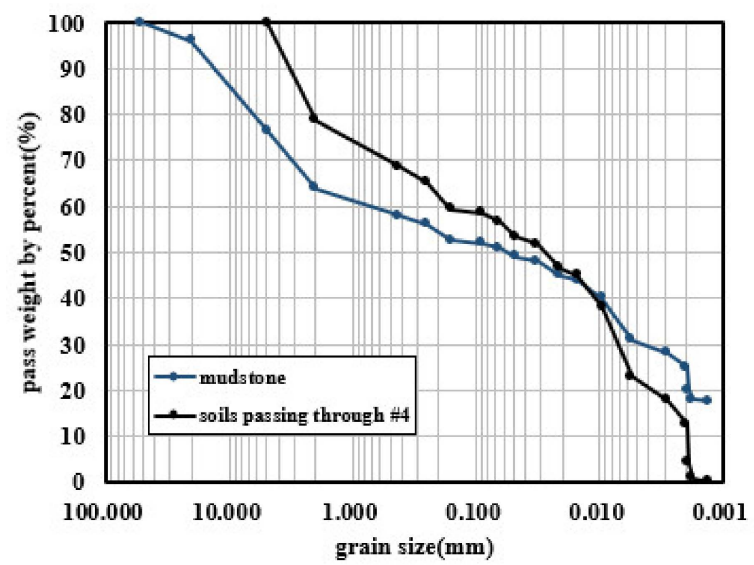

Figure 4. Particle size distribution curves of mudstone original soils and soils passing through \#4.

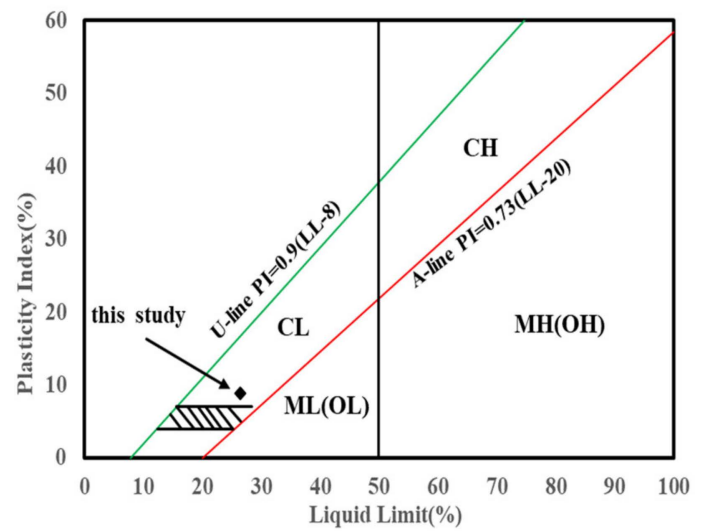

Figure 5. Testing soils in the paper located within the plastic chart according to the United Soils Classification System.

\subsection{Compaction Test}

As per ASTM D698 and ASTM D1557, the improved and standard soil compaction tests were conducted to determine the compaction curves, maximum dry density $\gamma_{\mathrm{dmax}}$, and OMC. The present study distinguished clods with varying grain sizes and cement content to conduct improved and standard soil compaction tests. Curves of soil graduations for soil that passed through the sieves ( $<\# 4, \# 4-3 / 4^{\prime \prime}$, or larger than $\left.3 / 4^{\prime \prime}\right)$ were adopted to simulate clod size for tests involving the varying cement content levels of $0 \%, 4 \%$, and $8 \%$. Figure 6 presents the compaction curve results, with $x$ - and $y$-axis denoting soil water content and dry density, respectively. Figure 6a indicates that larger clod grain sizes led to the rightward and downward movement of the compaction curves. The improved soil compaction curve was positioned to the upper-left side of the standard soil compaction curves. Figure $6 \mathrm{~b}$ indicates that an increase in added cement caused the maximum dry density of both improved soil and standard soil compaction curves to move downward, indicating an increase in OMC and decrease in maximum dry density. The improved soil compaction test results revealed that the mudstone specimen OMC and $\gamma_{\mathrm{dmax}}$ were $10.1 \%$ and $19.9 \mathrm{kN} / \mathrm{m}^{3}$, respectively. When the cement addition $\mathrm{C}$ was $4 \%$ and $8 \%$, the OMC levels were $10.8 \%$ and $11.6 \%$, respectively, and the maximum dry density levels were 19.6 $\mathrm{kN} / \mathrm{m}^{3}$ and $19.5 \mathrm{kN} / \mathrm{m}^{3}$, respectively. For subsequent specimen preparation, compaction test results were employed as the basis, and a line was drawn approximately parallel to the zero air void curve (ZAVC) along the compaction curve on the wet side; this line represents the $S_{r}=91 \%$ curve (Figure 6). The curve was used as the basis for controlling moisture content for each dry density level during specimen preparation. The relevant moisture content levels for dry density levels of $17.5,18.0,18.5,19.0,19.5$, and $20.0 \mathrm{kN} / \mathrm{m}^{3}$ were 
$16.2 \%, 15.8 \%, 15.2 \%, 14.0 \%, 12.3 \%$, and $10.1 \%$, respectively. The moisture content controls for mudstone-cement specimens were identical.

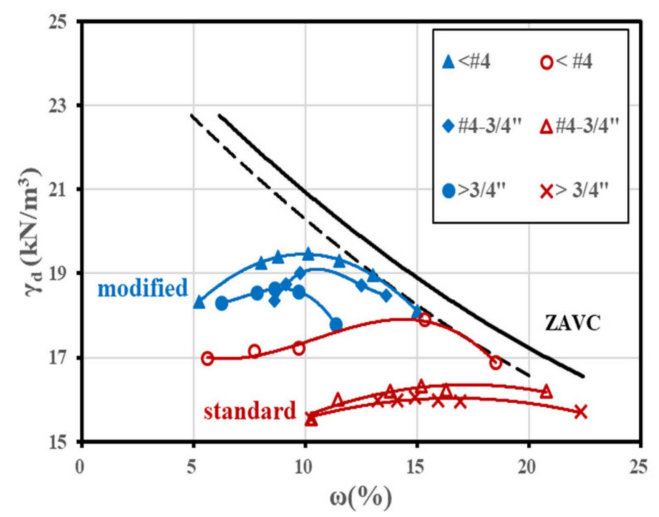

(a)

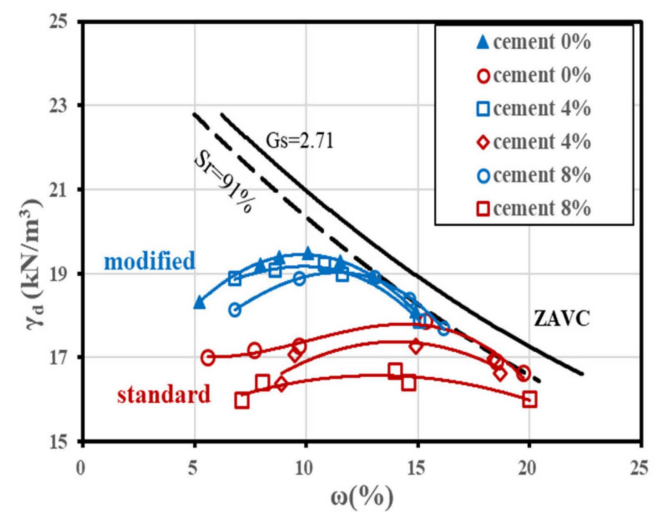

(b)

Figure 6. Compaction curves and zero air void curves (ZAVC) from the compaction tests for various mix conditions: (a) mudstone; (b) mudstone-cement.

\subsection{Unconfined Compression Test}

After dry cement is mixed with mudstone clods, the hydration of cement produces gels that fill a void. The gel increases the compactness of the clay framework and improves the clods. To understand the effectiveness of the implemented improvements, unconfined compression strength was used as the basic indicator of mudstone that was improved with the addition of cement. Unconfined compression tests were conducted per ASTM D2166. The tested items included specimen preparation methods, clods, number of curing days, cement addition, moisture content, and dry density variables. An explanation and analysis of the treated and untreated soil samples are provided. Figure 7a presents the curves for an untreated specimen clod with grains that passed through \#4 sieves, with static methods used to prepare the specimens. Dry density ranged from 17.5 to $20.0 \mathrm{kN} / \mathrm{m}^{3}$, the unconfined compression strength ranged from to $15.1 \mathrm{kPa}$, and the corresponding stain ranged from $0.83 \%$ to $1.74 \%$. Unconfined compression strength appeared to increase with an increase in dry density. Similar trends were observed for the other two clod grain sizes. Figure $7 \mathrm{~b}$ presents the treated specimens of various clods with a dry density of $19.5 \mathrm{kN} / \mathrm{m}^{3}$. Grains that passed through a \#4 sieve yielded an unconfined compression strength of $98.0 \mathrm{kPa}$ and a corresponding strain of $1.53 \%$. The unconfined compression strength of grains that were retained through the \#4-3/4" sieve was $95.1 \mathrm{kPa}$ and the corresponding strain was $1.59 \%$. The unconfined compression strength of grains that passed through or were retained on a $3 / 4^{\prime \prime}$ sieve was $57.0 \mathrm{kPa}$ and the corresponding strain was $1.28 \%$. In summary, the unconfined compression strength was highest for clod grain that passed through the \#4 sieve, followed by the \#4-3/4" sieve and $>3 / 4$ " sieve. Figure 8 a presents the relationship between unconfined compression strength $\mathrm{q}_{\mathrm{u}}$ and dry density $\gamma_{\mathrm{d}}$ of mudstone specimen clods. It indicates that the compaction method generated the highest unconfined compression strength, followed by the static and kneading methods. The treated specimens with $C=8 \%$ and grains that passed through the \#4 and \#4-3/4" sieves after 28 days of curing exhibited higher unconfined compression strength $\mathrm{q}_{\mathrm{u}}$ relative to the other specimens. In 2021, Wu et al. [26] proposed that the two factors cement and density influence the strength of marine clay that is improved through the use of cement. Figure 8a indicates that the mudstone specimens with six dry density levels yielded unconfined compression strength levels of between 10 and $400 \mathrm{kPa}$. However, after $8 \%$ cement paste was added to the specimens, which were then cured for 28 days, the specimens' unconfined compression strength increased to between 500 and $1200 \mathrm{kPa}$. Under the research conditions proposed by the present study, the addition of cement paste was more effective than an increase in dry density. 


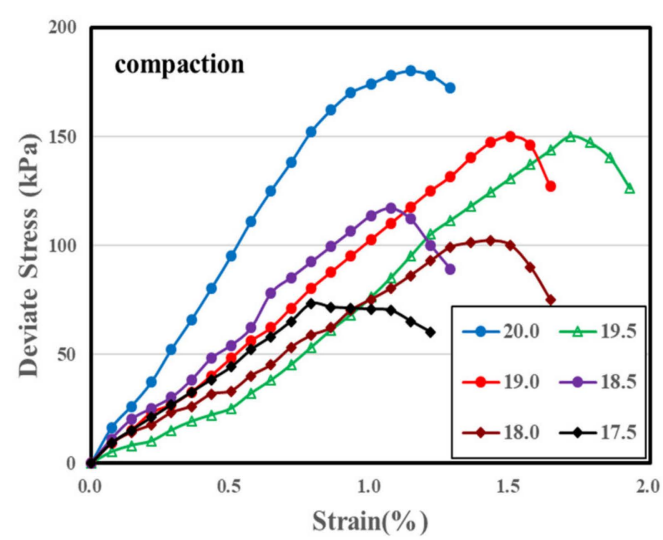

(a)

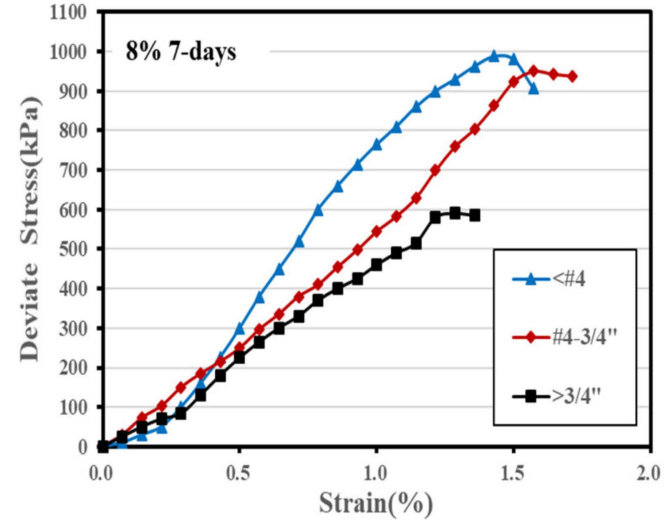

(b)

Figure 7. Deviate stress-strain curves of untreated and treated samples of unconfined compression test: (a) mudstone; (b) mudstone-cement.

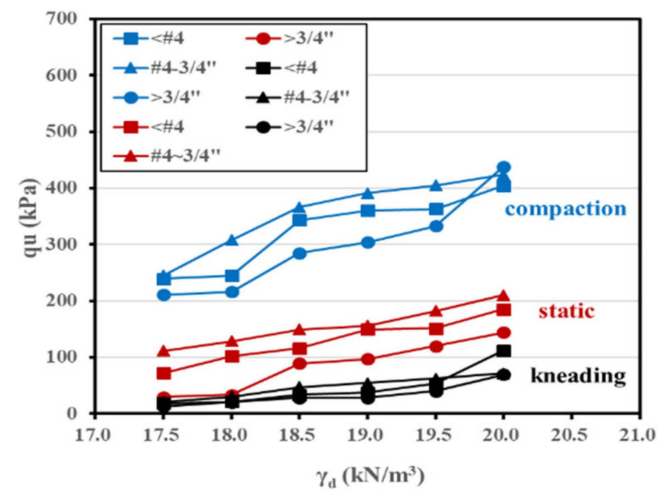

(a)

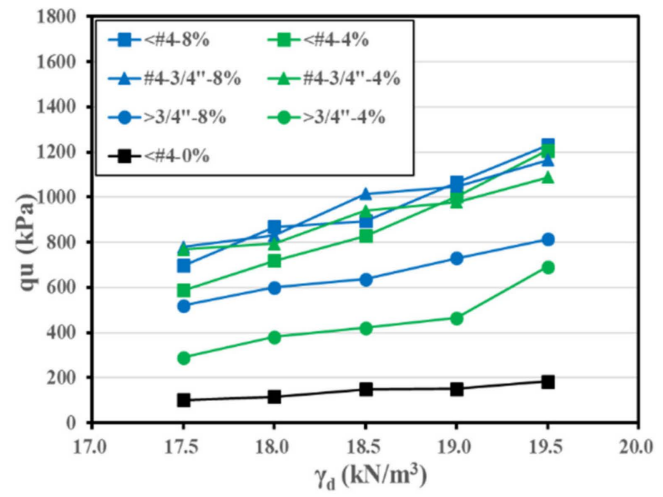

(b)

Figure 8. Unconfined compression strength with respect to dry density in soil samples for untreated and treated samples: (a) mudstone; (b) mudstone-cement.

Figure $9 \mathrm{a}, \mathrm{b}$ presents the relationships between elastic modulus $\mathrm{E}_{50}$ and dry density $\gamma_{\mathrm{d}}$ in mudstone and mudstone-cement specimens, respectively. The trends presented by the aforementioned figures were identical to those in Figure 8. Among the mudstone specimens with six dry density levels, their elastic modulus $\mathrm{E}_{50}$ was between 1 and $24 \mathrm{MPa}$. After the specimens with added cement paste underwent 28 days of curing, their elastic modulus $\mathrm{E}_{50}$ was between 20 and $120 \mathrm{MPa}$. The relationships between elastic modulus $\mathrm{E}_{50}$ and unconfined compression strength $\mathrm{q}_{\mathrm{u}}$ (Figures 8 and 9) are plotted in Figure 10. For the mudstone specimen formula, $\mathrm{E}_{50}=47.699 \mathrm{qu}_{\mathrm{u}}$ and $\mathrm{R}^{2}=0.8708$, whereas for the mudstone-cement specimen formula, $E_{50}=69.397 q_{u}$ and $R^{2}=0.9693$. In 2017, Jamsawang et al. [19] used cement and fly ash to improve clay and reported that for the unsoaked sample, $E_{50}=90 q_{u}$ and $R^{2}=0.9890$, whereas for the soaked sample, $E_{50}=60 q_{u}$ and $R^{2}=0.9894$. In 2021, Wu et al. [26] indicated that the density control group had a formula of $E_{50}=131.1 q_{u}$ and $R^{2}=0.89$, whereas the cementation control group had a formula of $E_{50}=60.4 q_{u}$ and $R^{2}=0.84$. The difference in the formula coefficients was dependent on the added paste material and specimen preparation methods. 


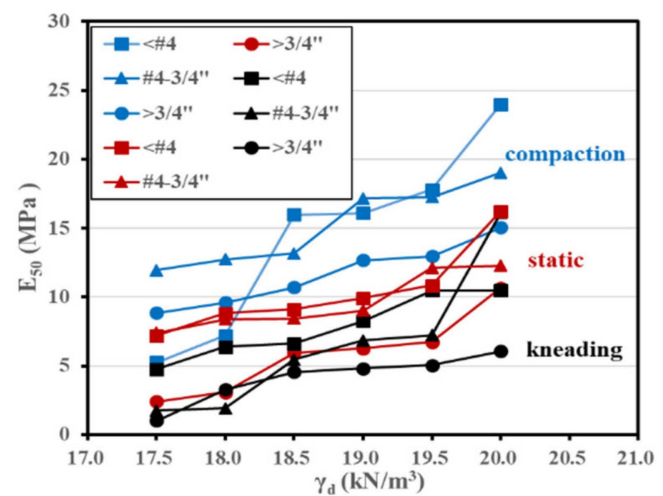

(a)

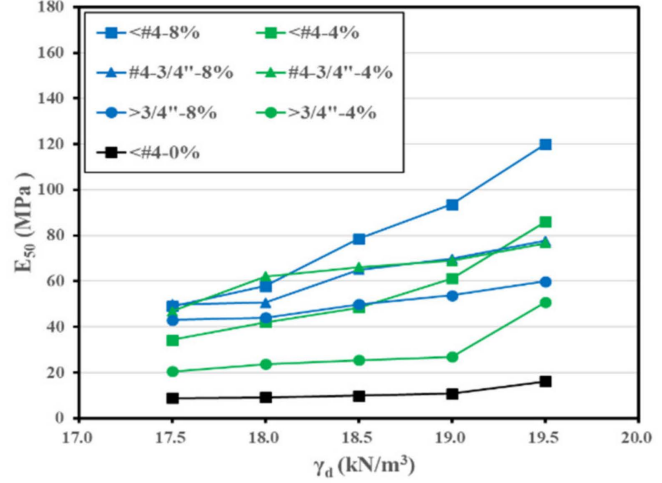

(b)

Figure 9. Elastic modulus $\mathrm{E}_{50}$ with respect to dry density for untreated and treated samples: (a) mudstone; (b) mudstone-cement.

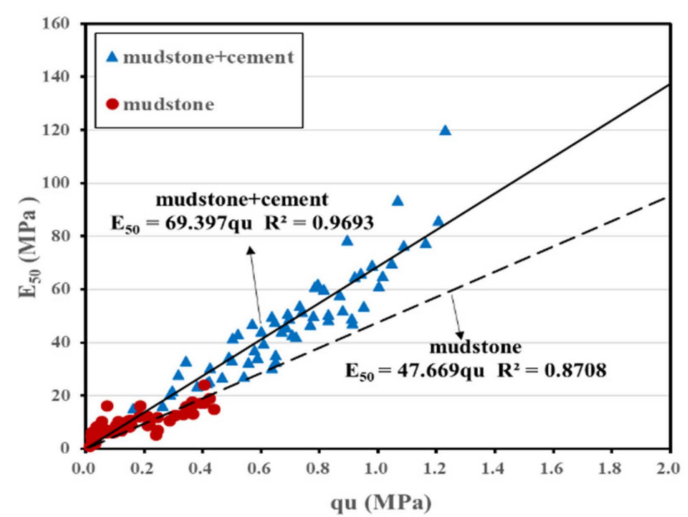

Figure 10. The relationships between $q_{u}$ and $E_{50}$ values based on mudstone and mudstonecement samples.

\subsection{Triaxial CU Test}

In 2017, Das and Sobhan [34] proposed the use of triaxial CU test parameters to simulate load bearing-related engineering problems that are encountered shortly after completing the initial compaction of soil. The present study used ELE International's Digitest 50 system to conduct tests. The strain was controlled at $1.06 \mathrm{~mm} / \mathrm{min}$. The pneumatic loading system was connected to a measuring system, which considered load cells, LVDT, volume changes, and pore water pressure sensors. A set of data loggers was used to establish a connection with a computer for data storage and analysis. As per ASTM D2850, triaxial CU tests were conducted. The testing stages included specimen preparation, saturation, confining pressure, consolidation, and application of deviator stress. Specimen saturation requires the Skempton pore water pressure parameter $B$ value to be at least 0.95 . After the saturation stage, we can measure the B value by applying incremental confining pressure. The consolidation stage involved the complete exclusion of excess pore water pressure inside specimens. The present study used three grain sizes (grains that passed

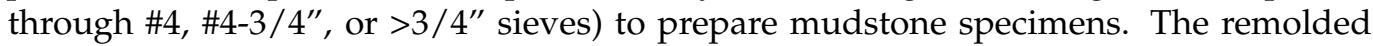
specimens with added cement paste were prepared using static methods. The confining pressures of the specimens were 50, 100, and $200 \mathrm{kPa}$. Figure 11 presents the triaxial CU test results of original mudstone soil and treated soil samples. Figure 11a presents the original soil stress-strain curves. When the strain was between $10 \%$ and $15 \%$, the deviator stress peaked and then gradually decreased. The pore water pressure peaked when the strain was between $0 \%$ and $5 \%$, which dropped sharply afterward. When the deviator stress was at its peak, the pore water pressure was between -20 and $-60 \mathrm{kPa}$. Figure $11 \mathrm{~b}$ presents the triaxial CU test results of specimens with added cement. The results revealed that when the strain was between $1.5 \%$ and $2.0 \%$, deviator stress peaked and then gradually decreased. 
The pore water pressure peaked at a strain of $0.5 \%$ and decreased sharply afterward. When stress peaked, the pore water pressure was between -20 and $-80 \mathrm{kPa}$.
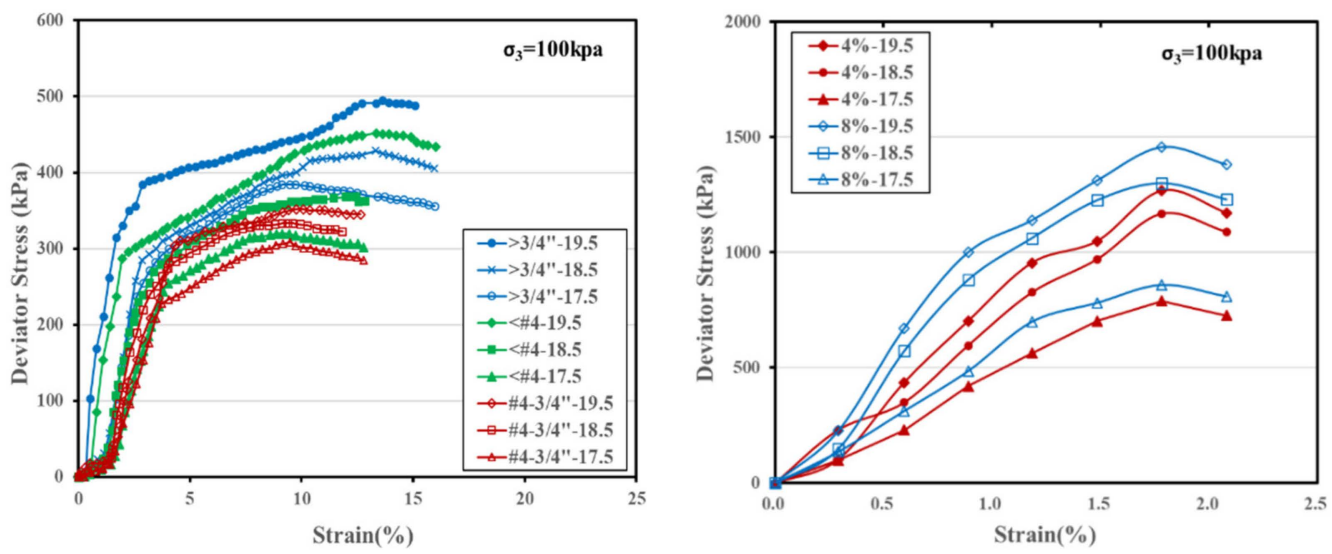

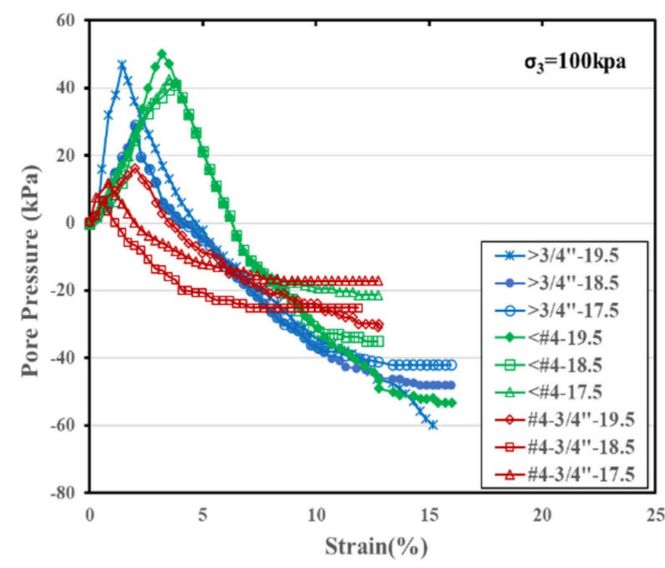

(a)

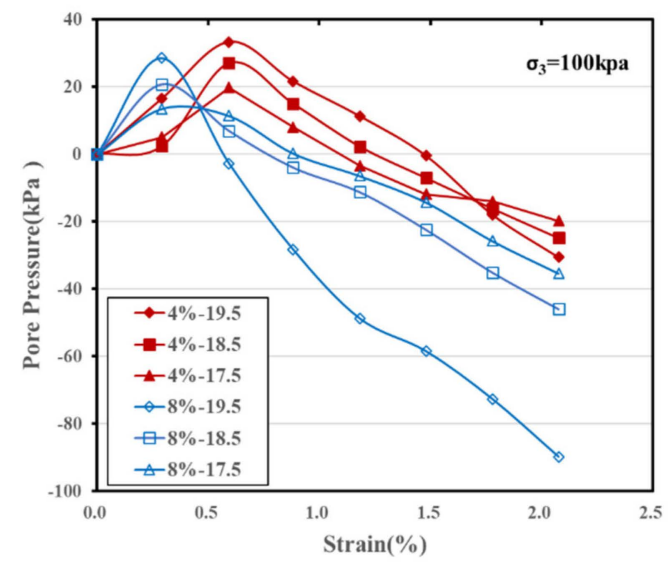

(b)

Figure 11. Typical triaxial Consolidated Undrained test results for untreated and treated samples: (a) mudstone; (b) mudstone-cement.

In all tests, shear strength increased with an increase in cement content and dry density. Figure 12 uses various confined compression Mohr circles and failure envelope curves to present the triaxial CU test results of the original mudstone soil and mudstone-cement soil samples. Because the specimens were compacted and contained cement paste, the pore water pressure was negative when the deviator stress was at its peak. At that point, effective stress and soil shear strength should increase. Consoli et al. [16] conducted saturated soil triaxial UU tests and reported negative pore water pressure. Figure 12 indicates that when the specimen $\gamma_{\mathrm{d}}$ was $19.5 \mathrm{kN} / \mathrm{m}^{3}$ and cured for 28 days with $\mathrm{C}=0 \%, 4 \%$, or $8 \%$, the $\mathrm{c}$ values were $85 \mathrm{kPa}, 147 \mathrm{kPa}$, and $167 \mathrm{kPa}$, respectively, and the $\phi$ angles were $25.79^{\circ}$, $44.37^{\circ}$, and $44.35^{\circ}$, respectively. The cohesion force and internal friction angle increased when the amount of paste added was increased. Figure 13 presents the CU test results for mudstone and mudstone-cement specimens, including the total stress c values and $\phi$ angles. Figure 13a indicates that among the various clods, when $\gamma_{\mathrm{d}}$ increased, the $\phi$ angle increased notably to between $23.5^{\circ}$ and $27.6^{\circ}$. However, the increase in the c value was not substantial, which could be related to the pore water pressure at specimen failure. The results of the mudstone-cement samples are presented in Figure 13b. C (i.e., amount of cement added) was $4 \%$ or $8 \%$ and the angle was between $37.1^{\circ}$ and $44.8^{\circ}$. 


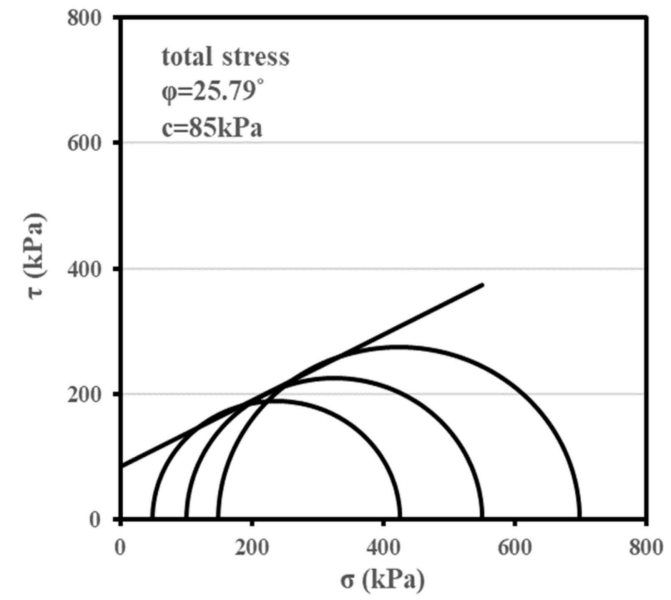

(a)

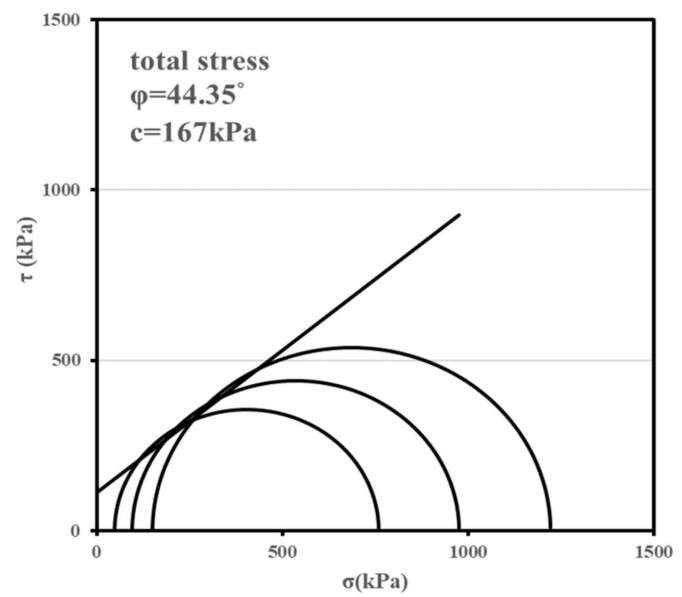

(c)

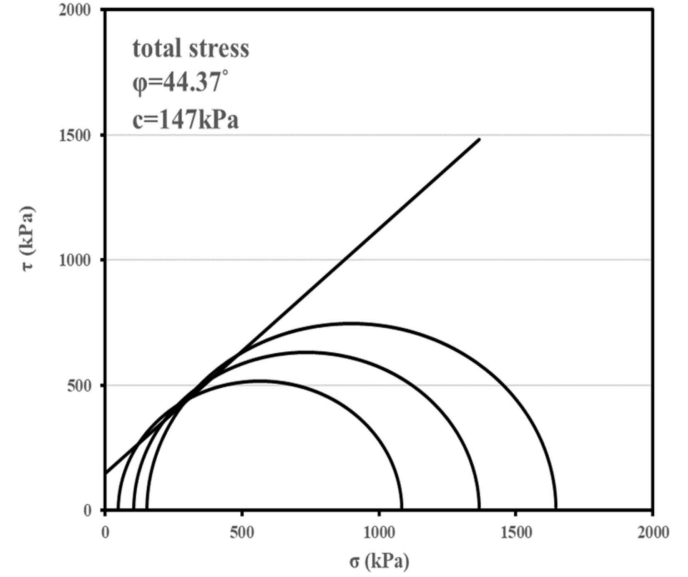

(b)

Figure 12. Mohr circle and shear strength parameters of the testing samples for triaxial Consolidated Undrained tests: (a) CU-0\%; (b) CU-4\%; (c) CU-8\%.

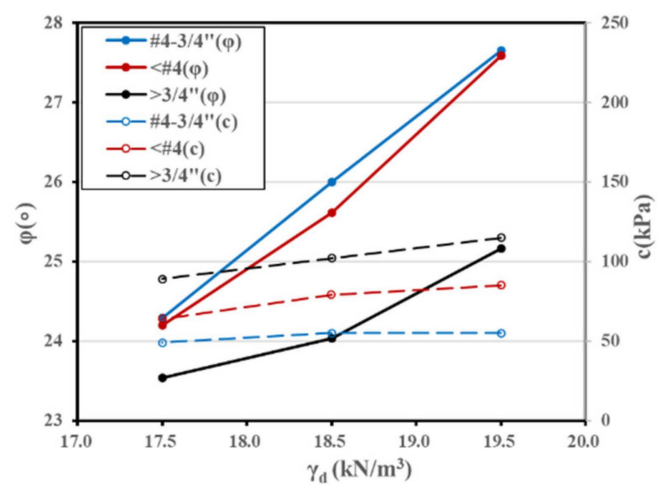

(a)

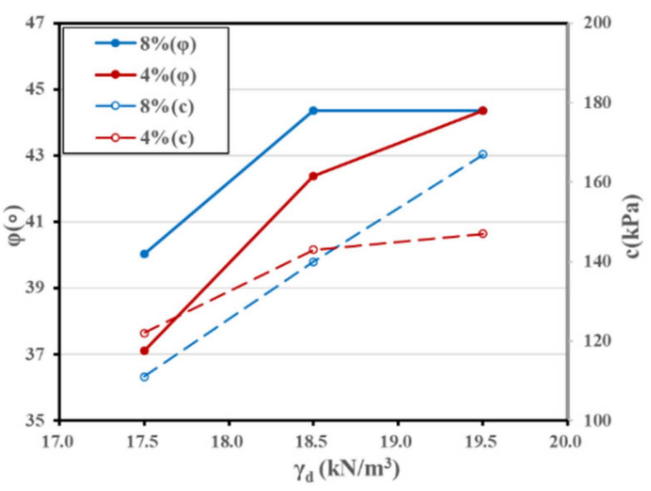

(b)

Figure 13. Cohesion values and internal friction angles of the samples for triaxial Consolidated Undrained tests: (a) mudstone; (b) mudstone-cement.

\subsection{Triaxial UU Test}

Das and Sobhan [34] proposed the use of the parameters of triaxial UU tests for simulating clay stability analysis and calculating bearing capacity when a construction load is high. To prepare remolded specimens, the present study used static triaxial UU tests. A discussion of mudstone and mudstone-cement specimens follows. Similar test 
methods were used and the specimens did not achieve saturation. Das [48] and Fredlund and Rahardjo [49] indicated that the curved envelope is sometimes approximated as a straight line as Equation (1) in unsaturated soils for design purposes. Care should be taken to not exceed the limits to which the envelope is applicable. Figure 14 indicates that when the specimens had a $\gamma_{\mathrm{d}}$ of $19.5 \mathrm{kN} / \mathrm{m}^{3}$ and were cured for 28 days with $\mathrm{C}=0 \%$, $4 \%$, and $8 \%$, the c values were $70 \mathrm{kPa}, 154 \mathrm{kPa}$, and $256 \mathrm{kPa}$, respectively, and the $\phi$ angles were $27.26^{\circ}, 42.72^{\circ}$, and $43.13^{\circ}$, respectively. Cohesion and the internal friction angle increased with the amount of cement paste added. Clods with grains that passed through the \#4 and \#4-3/4" sieves did not exhibit considerable differences. Specimens retained by the $3 / 4^{\prime \prime}$ sieve exhibited greater clod grain sizes. After the completion of compaction, a large number of grains with varying sizes still existed in the specimens, preventing the complete compactness of the soil specimens. Therefore, specimens that were subjected to shearing forces tended to present dislocated grains and have reduced friction angles. Figure 15 presents the comparison diagrams for cement content, friction angle, and cohesion force. When the amount of cement paste added was increased, friction angle and cohesion force increased.

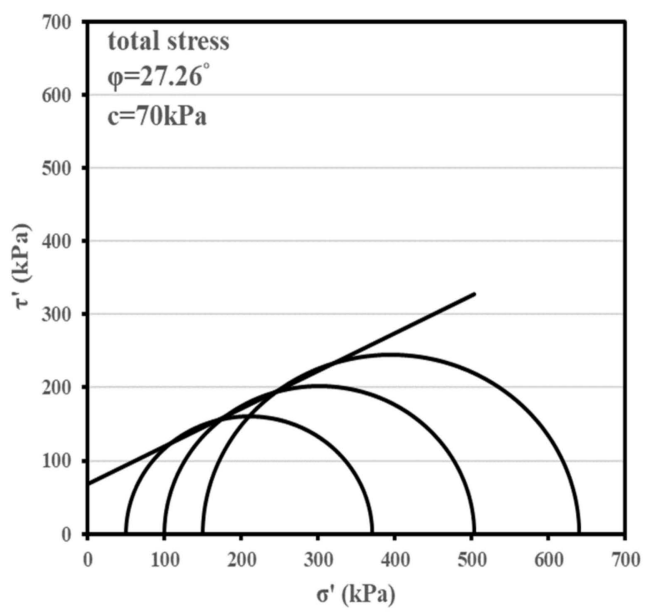

(a)

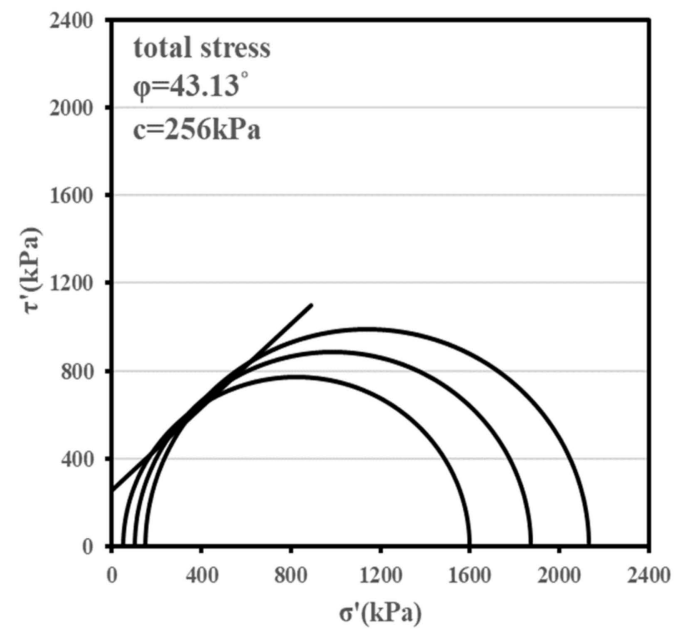

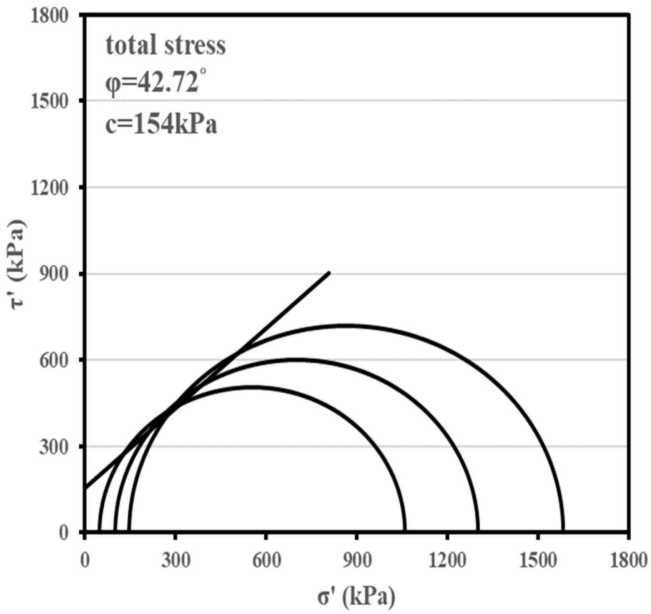

(b)

(c)

Figure 14. Mohr circle and shear strength parameters of the soil samples for triaxial Unsaturated Unconsolidated Undrain tests: (a) UU-0\%; (b) UU-4\%; (c) UU-8\%. 


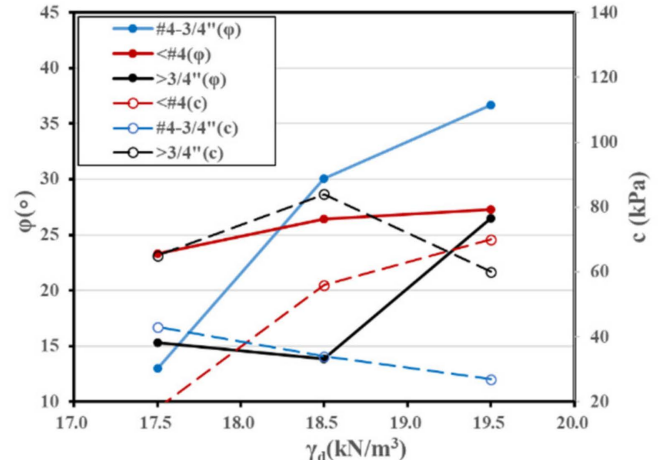

(a)

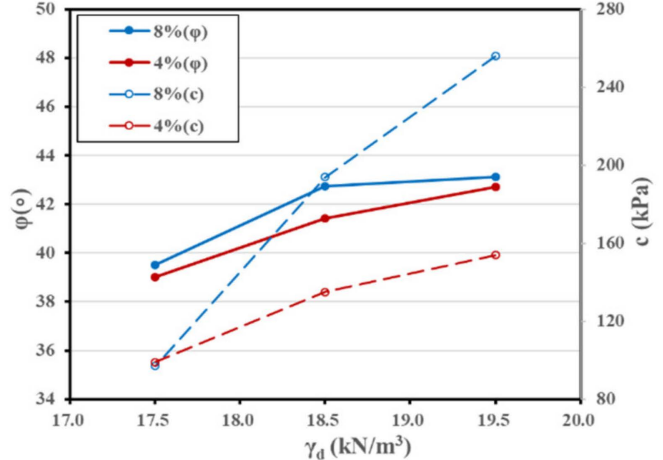

(b)

Figure 15. Cohesion values and internal friction circle of the samples for triaxial Unsaturated Unconsolidated Undrain tests: (a) mudstone; (b) mudstone-cement.

Unconfined compression strength measures the strength of specimens under unconfined conditions, with soil generally subjected to overburden pressure under the ground surface. Therefore, shear strength can be represented using Equation (1); that is, shear strength is calculated using the $c$ value and $\phi$ angle parameters. The data presented in Figures 12 and 14 are organized in Table 1 . For the parameter $\sigma$, a shallow overburden pressure of $40 \mathrm{kPa}$ was applied. The triaxial CU test specimens were set as saturated and the triaxial UU test specimens were set as unsaturated. The mudstone specimens had a $\mathrm{C}$ of $0 \%$, whereas the mudstone-cement specimens had a $\mathrm{C}$ of $4 \%$ and $8 \%$. After 28 days of curing, the shear strength $\tau_{\mathrm{f}}$ of saturated samples was $104.33 \mathrm{kPa}, 186.13 \mathrm{kPa}$, and $206.10 \mathrm{kPa}$, while that of unsaturated samples was $90.61 \mathrm{kPa}, 190.94 \mathrm{kPa}$, and $293.47 \mathrm{kPa}$. The relevant data are plotted in Figure 16, which indicates that unsaturated samples exhibited higher strength. The soaked samples generate negative pore water pressure because of compaction and the addition of cement under low strain conditions; thus, the specimen strength was not low. In Figure 8, the unconfined compression strength $\mathrm{q}_{\mathrm{u}}$ of specimens with $\mathrm{C}$ values of $0 \%, 4 \%$, and $8 \%$ after 28 days of curing was 151, 1207, and $1488 \mathrm{kPa}$, respectively. However, real geoengineering foundations are confined. Thus, the adoption of $\tau_{\mathrm{f}}$ is more suitable for engineering applications.

Table 1. Shear strength calculated by CU and UU test results.

\begin{tabular}{|c|c|c|c|}
\hline \multicolumn{4}{|c|}{ CU test } \\
\hline & mudstone & \multicolumn{2}{|c|}{ mudstone-cement } \\
\hline & $C=0 \%$ & $C=4 \%$ & $C=8 \%$ \\
\hline ' & 85 & 147 & 167 \\
\hline$\phi\left(^{\circ}\right)$ & 25.79 & 44.37 & 44.35 \\
\hline$\tau \mathrm{f}(\mathrm{kPa})$ & 104.33 & 186.13 & 206.10 \\
\hline \multicolumn{4}{|c|}{ UU test } \\
\hline & mudstone & mudstone-cement & \\
\hline & $C=0 \%$ & $C=4 \%$ & $C=8 \%$ \\
\hline $\mathrm{c}(\mathrm{kPa})$ & 70 & 154 & 256 \\
\hline$\phi\left(^{\circ}\right)$ & 27.26 & 42.72 & 43.13 \\
\hline$\tau \mathrm{f}(\mathrm{kPa})$ & 90.61 & 190.94 & 293.47 \\
\hline
\end{tabular}




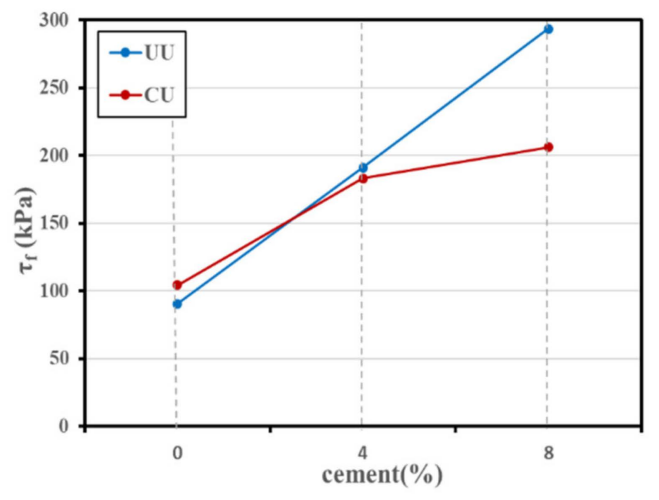

Figure 16. Comparison of shear strength of the samples for triaxial Consolidated Undrained and Unsaturated Unconsolidated Undrain test.

\subsection{Triaxial Permeability Test}

The indoor permeability test was based on the ASTM D2434 test and performed using a triaxial method. Infiltration was calculated using Darcy's law, that is,

$$
\mathrm{q}=\mathrm{kiA} \text {, }
$$

where $\mathrm{i}$ is the hydraulic gradient and $\mathrm{A}$ is the circulation area. The specimen was approximately $10 \mathrm{~cm}$ in length, and its upper and lower hydraulic head gap was $50 \mathrm{kPa}$, indicating that the hydraulic gradient $i=500 / 10=50$. Each test required approximately 1 week for flow rate to stabilize before measurements were taken. Studies have explored the hydraulic conductivity of mudstone in Taiwan. They include a 1998 study by Sheu et al. [40], who reported that excessively high or low moisture content on both the dry and wet sides of compacted OMC resulted in high hydraulic gradient $k$ values, and a 2004 study by Hsiao and Lin [34], who reported that reduced compaction energy and overly large grain sizes led to a substantial increase in the hydraulic gradient. In the present study, the triaxial permeability test was conducted to examine three clod grain sizes and two dry density levels, with the test revealing that the $\mathrm{k}$ values of the soil specimens ranged between $10^{-4}$ and $10^{-7} \mathrm{~cm} / \mathrm{s}$. Excluding the clods with grain sizes larger than $3 / 4^{\prime \prime}$, other specimens exhibited low permeability or impermeability. These results corresponded to the impermeability characteristics of mudstone. A specimen with added cement paste $(C=4 \%)$ was used for testing. After 1 week, no notable water effluence was observed from the specimen, which was then regarded to be almost impermeable. Figure 17 presents the relationships between dry density and hydraulic conductivity for each specimen. When the size of clod grains increased, the hydraulic gradient $\mathrm{k}$ increased. Grain size was not directly associated with dry density. Although the soil was compacted, a considerable number of large-sized grains still existed in the clods, thereby leading to the formation of a substantial void among grains in the clods and greater hydraulic conductivity. Benson and Daniel [31] reported similar test results in their 1989 study.

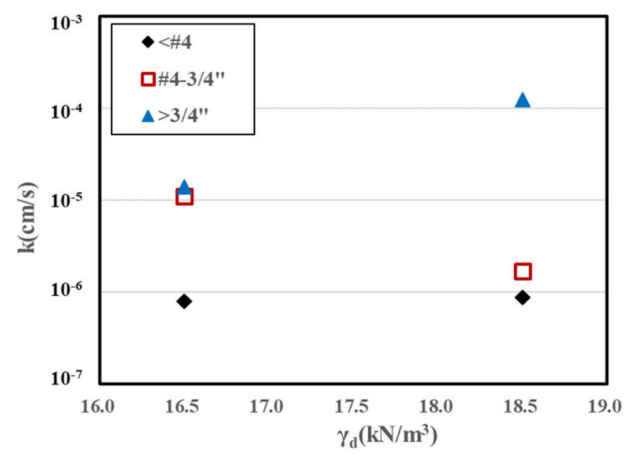

Figure 17. Permeability coefficient vs. dry density for different clods samples. 


\subsection{One-Dimension Consolidation Test}

The one-dimension consolidation test was based on ASTM D2435. The loaded weights were $25,50,100,200,400,800$, and $1600 \mathrm{kPa}$, and the loading time was $24 \mathrm{~h}$. Seven sets of tests were conducted to examine untreated soil specimens, treated specimens with $4 \%$ and $8 \%$ cement content, and three dry density levels. The test results are presented in Figure 18. Figure 18a indicates that the compaction level of mudstone soil was the highest. Specimens with $4 \%$ cement content exhibited flat straight lines of compaction when dry density was increased, suggesting low compaction levels. Figure $18 \mathrm{~b}$ displays a similar trend. The results were used to calculate the compression index $C_{c}$ and swelling index $C_{s}$. Figure 19a indicates that for specimens with $C=4 \%$ and dry density levels of $17.5,18.5$, and $19.5 \mathrm{kN} / \mathrm{m}^{3}$, their corresponding $C_{c}$ values were $0.034,0.031$, and 0.022 , respectively. For specimens with $\mathrm{C}=8 \%$ and dry density levels of $17.5,18.5$, and $19.5 \mathrm{kN} / \mathrm{m}^{3}$, their corresponding $C_{c}$ values were $0.028,0.025$, and 0.016 , respectively. The $C_{c}$ value of the soil specimen without cement content was 0.142 . The results suggested that an increase in cement content and dry density reduced compression indexes. Thus, the addition of cement was effective in inhibiting soil consolidation settlement. Figure 19b indicates similar results for the swelling index $C_{s}$. In 2015, Zeng et al. [50] proposed that clay's initial moisture content and LL considerably affect remolded clay specimens' compression indexes. The present study used specimens with low moisture content and a LL of $26.8 \%$; thus, the $\mathrm{C}_{\mathrm{C}}$ value obtained in this study was not high. After cement paste was added, the compression index further decreased.

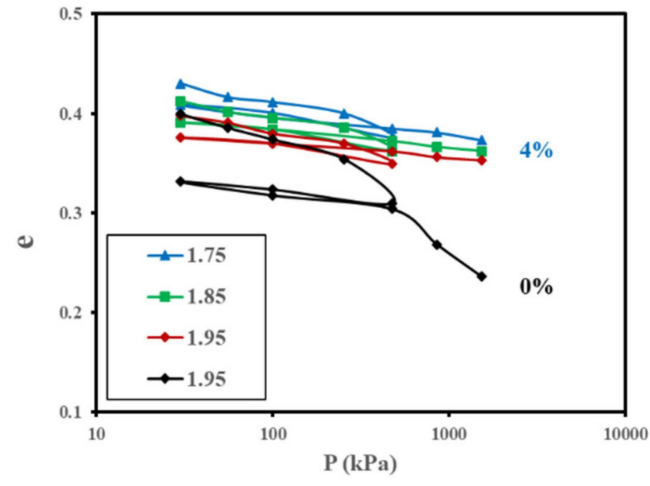

(a)

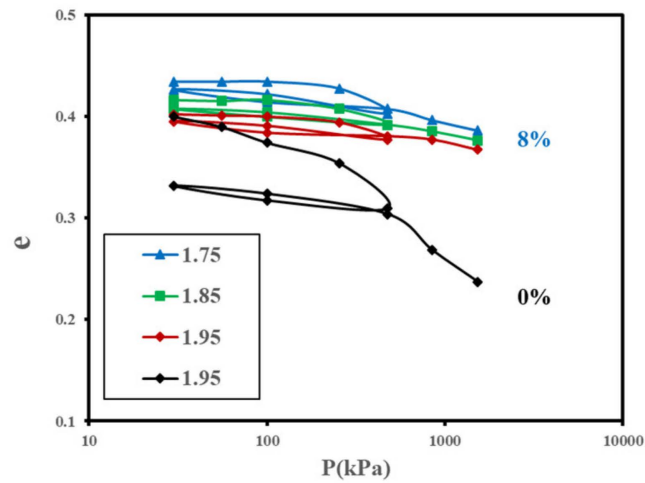

(b)

Figure 18. Compression curves of untreated and treated samples based on a soil consolidated test: (a) mudstone and mudstone-cement with $\mathrm{C}=4 \%$; (b) mudstone and untreated mudstone-cement with $\mathrm{C}=8 \%$.

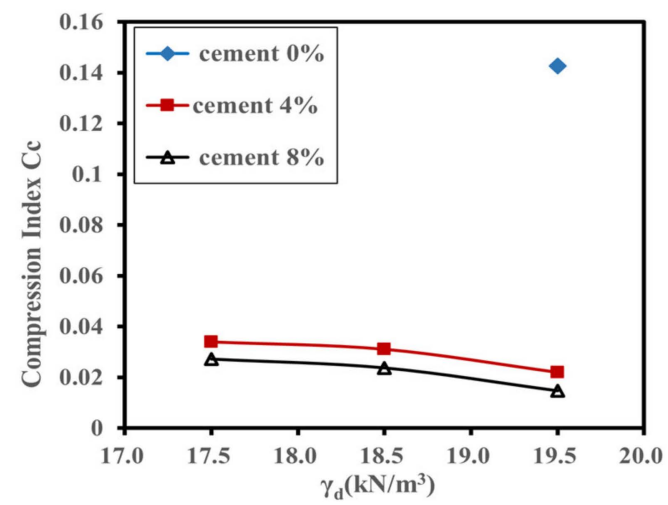

(a)

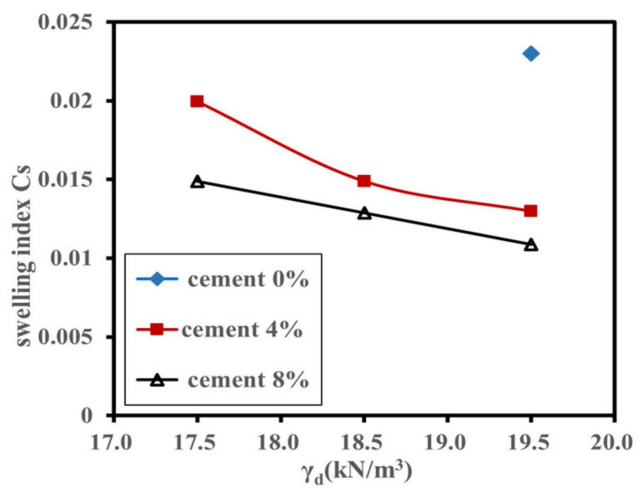

(b)

Figure 19. A comparison of compression index $C_{c}$ and swelling index $C_{s}$ versus testing soils dry density levels: (a) $C_{c}$ versus $\gamma_{d}$; (b) $C_{s}$ versus $\gamma_{d}$. 


\subsection{CBR Test}

The CBR test was based on ASTM D1883 and D4429 and the indoor test was based on ASTM D1883. Each group consisted of specimens that were compacted 10 times, 25 times, and 56 times. The relationships between CBR and dry density were obtained. The CBR corresponding to the $95 \% \gamma_{\mathrm{dmax}}$ of the compaction test was the true CBR. The test specimens were divided into $0 \%, 4 \%$, and $8 \%$ added cement. Figure 20 a presents the CBRs corresponding to a $95 \%$ maximum dry density. The CBRs of specimens with $0 \%$, $4 \%$, and $8 \%$ added cement were $15.6 \%, 93 \%$, and $123 \%$, respectively. The graph presents the relationship between dry density and CBR for three compaction patterns. When the number of compactions and cement content increased, the CBRs also increased. Thus, a concurrent increase in compaction energy and added cement led to a considerable increase in soil bearing capacity. Figure 20b indicates that when the number of compactions and amount of added cement increased, the swelling ratios decreased. In 1994, Lee et al. [3] suggested that that swelling of mudstone in Taiwan is related to clay minerals; specifically, the montmorillonite content of mudstone in Renwu is low.

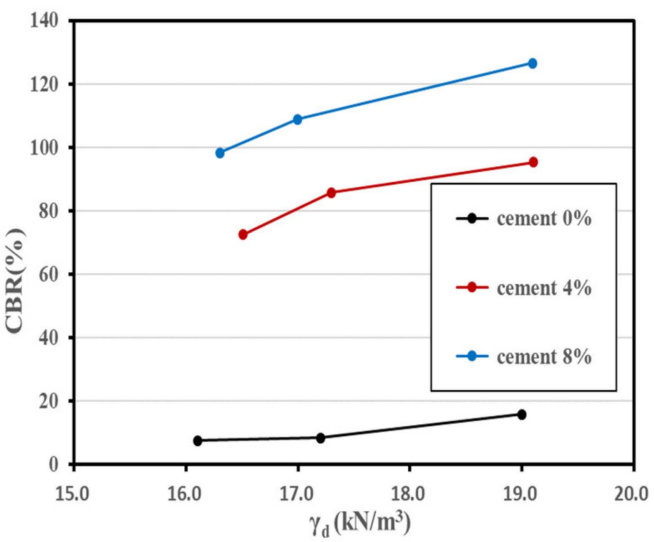

(a)

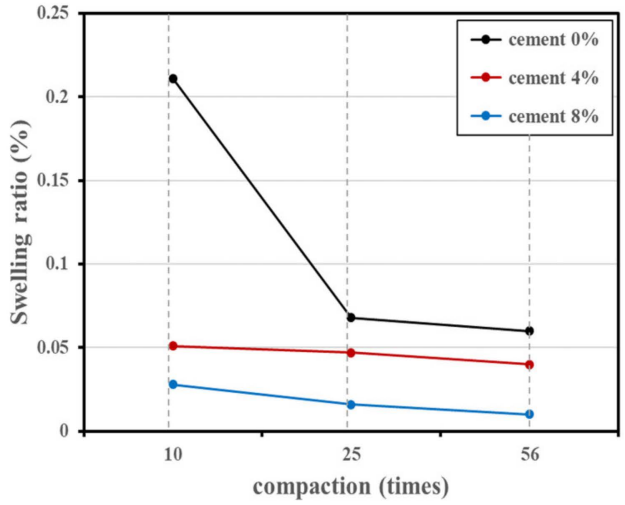

(b)

Figure 20. CBR values and swelling ratio for treated soils: (a) CBR versus $\gamma_{d}$; (b) Swelling ratio versus compaction (times).

\section{Conclusions}

The main objectives of the present study were to explore the multiple mechanical and engineering properties of mudstone improved with the increasing density or addition of $4 \%$ and $8 \%$ dry cement. Thus, mudstone clods with three grain sizes (grains that passed through \#4, \#4-3/4", or $>3 / 4$ " sieves) were examined. Three methods (compaction, kneading, and static) and six dry density levels were used to prepare specimens. Two cement content levels were also applied. The following conclusions are drawn.

1. For the compaction tests, specimen moisture content was controlled and unconfined compression strength increased with $\gamma_{\mathrm{d}}$. The compaction method produced specimens with the highest strength. In contrast, the clods with grain sizes larger than $3 / 4^{\prime \prime}$ exhibited the lowest strength. The clod effect was similar with the results of the triaxial permeability test. The hydraulic gradient $\mathrm{k}$ values of mudstone clods ranged between $10^{-4}$ and $10^{-7} \mathrm{~cm} / \mathrm{sec}$, indicating low permeability or no permeability and that the hydraulic gradient $\mathrm{k}$ values of mudstone increased in relation to clods.

2. The mudstone specimen formula yielded $E_{50}=47.699 q_{u}$ and $R^{2}=0.8708$, while the mudstone-cement formula yielded $\mathrm{E}_{50}=69.397 \mathrm{qu}$ and $\mathrm{R}^{2}=0.9693$. By comparing our study with those that used formulas proposed by other researchers, we found that the differences between coefficients could be attributed to the material added and specimen preparation methods.

3. The triaxial CU and UU test results were used to calculate shear strengths through the application of the Mohr-Coulomb formula. For mudstone supplemented with 
cement paste, its $\mathrm{q}_{\mathrm{u}}$ values increased 7 - to 10 -fold and shear strength values increased 2 - to 3 -fold. Thus, the choice of the strength testing method is vital for geotechnical consideration.

4. The results from the one-dimension compression test indicate that the addition of cement for soil improvement is effective in inhibiting consolidation settlement. In addition, an increase in the number of compactions and amount of cement added led to a decrease in the swelling ratio according to the CBR test results. Therefore, an increase in compactions and cement addition are good ways to improve the property of mudstone.

5. Taken together, our study demonstrates the application of engineering techniques and the addition of small amounts of cement. This method not only adheres to low-carbon and environmental protection requirements, but also verifies the feasibility of using compacted mudstone as an engineering material.

Author Contributions: Project administration, D.H.; Experimental and analysis, D.H.; Supervision, D.H.; Writing—original draft preparation and editing, D.H; Validation; C.H.; Writing-review, C.H. All authors have read and agreed to the published version of the manuscript.

Funding: Not applicable.

Institutional Review Board Statement: Not applicable.

Informed Consent Statement: Not applicable.

Data Availability Statement: All data is available upon request.

Acknowledgments: CTCI Co. in Taiwan supplied materials to support the experiment's requirements throughout. All experimental works were performed in the geotechnical laboratory in NKUST, whose assistance is appreciated. The copy editing assistance provided by Hsiang-Jung Hsiao is also appreciated.

Conflicts of Interest: The authors declare no conflict of interest.

\section{References}

1. Goodman, R.E. Engineering Geology-Rock in Engineering Construction; Wiley: New York, NY, USA, 2002.

2. Wang, T.T.; Huang, T.H. An experience of tunnelling in mudstone area in southwestern Taiwan. Tunn. Undergr. Space Technol. 1993, 17, 425-436. [CrossRef]

3. Lee, D.H.; Jhin, Y.Y.; Tien, K.G. Characteristics of mudstone and the methods for slope protection. Sino-geotechnics 1994, $48,35-47$.

4. Lee, D.H.; Tien, K.G.; Juang, C.H. Full-scale field experimentation of a new technique for protecting mudstone slopes, Taiwan. Eng. Geol. 1996, 42, 51-63. [CrossRef]

5. Lee, D.H.; Yang, Y.E.; Lin, H.M. Assessing slope methods for weak rock slopes in Southwestern Taiwan. Eng. Geol. 2007, 91, 100-116. [CrossRef]

6. Higuchi, K.; Chigira, M.; Lee, D.H.; Wu, J.H. Pore-water chemistry and its influence on rock mechanical properties and hydrogeophysical processes in a mudstone slope in the southwestern Taiwan badlands. Catena 2020, 190, 104533. [CrossRef]

7. Zhao, C.; Zhao, D. Application of construction waste in the reinforcement of soft soil foundation in coastal cities. Environ. Technol. Innov. 2021, 21, 101195. [CrossRef]

8. Arulyajah, A.; Nikraz, H.; Bo, M.W. Assessment of marine clay improvement under reclamation fills by in-situ testing methods. Geotech. Geol. Eng. 2006, 24, 219-226. [CrossRef]

9. Bayesteh, H.; Sabermahani, M. “Field study on performance of jet grouting in low water content clay. Eng. Geol. 2020, 264, 105314. [CrossRef]

10. Wang, M.; Xu, X.; Li, J.; Shen, F.; Li, Y. An experiment study on stress relaxation of unsaturated lime-treated expansive clay. Environ. Earth Sci. 2017, 76, 241. [CrossRef]

11. Zhang, Y.S.; Guo, C.B.; Yao, X.; Qu, Y.G.; Zhou, N.J. Engineering geological characterization of clayey diatomaceous earth deposits encountered in highway projects in the Tengchong region, Yunnan, China. Eng. Geol. 2013, 167, 95-104. [CrossRef]

12. Chan, C.M. Influence of mix uniformity on the induced solidification of dredged marine clay. Environ. Earth Sci. 2014, 71, 1061-1071. [CrossRef]

13. Li, J.S.; Xue, Q.; Wang, P.; Liu, L. Influence of leachate pollution on mechanical properties of compacted clay: A case study on behaviors and mechanisms. Eng. Geol. 2013, 167, 128-133. [CrossRef]

14. Hou, J.; Li, H.; Liu, L. An experimental study on microstructure of leachate-polluted stabilized clay. Environ. Earth Sci. 2018, 77, 636. [CrossRef] 
15. Miqueleiz, L.; Ramirez, F.; Seco, A.; Nidzam, R.M.; Kinuthia, J.M.; Abu Tair, A.; Garcia, R. The use of stabilised Spanish clay soil for sustainable construction materials. Eng. Geol. 2012, 133-134, 9-15. [CrossRef]

16. Consoli, N.C.; Foppa, D.; Festugato, L.; Heineck, K.S. Key parameters for strength control of artificially cemented soils. J. Geotech Geoenviron. Eng. ASCE 2007, 1332, 197-205. [CrossRef]

17. Edil, T.B.; Acosta, M.; Benson, C.H. Stabilizing soft fine-grained soils with fly ash. J. Mater. Civ. Eng. 2006, 182, 283-294. [CrossRef]

18. Hsiao, D.H.; Phan, T.A.V. Experimental investigation into compressive strength of soft soil stabilization under curing stress conditions. Electron. J. Geotech. Eng. 2014, 19, 10429-10446.

19. Jamsawang, P.; Poorahong, H.; Yoobanpot, N.; Songpiriyakij, S.; Jongpradist, P. Improvement of soft clay with cement and bagasse ash waste. Constr. Build. Mater. 2017, 154, 61-71. [CrossRef]

20. Liu, L.; Zhou, A.; Deng, Y.; Cui, Y.; Yu, Z.; Yu, C. Strength performance of cement/slag-based stabilized soft clays. Constr. Build. Mater. 2019, 211, 909-918. [CrossRef]

21. Lorenzo, G.A.; Bergado, D.T. Fundamental parameters of cement-admixed clay-New approach. J. Geotech. Geoenviron. Eng. ASCE 2004, 13010, 1042-1050. [CrossRef]

22. Preetham, H.K.; Nayak, S. Geotechnical investigations on marine clay stabilized using granulated blast furnace slag and cement. Int. J. Geosynth. Ground Eng. 2019, 5, 28. [CrossRef]

23. Anagnostopoulos, C.A.; Papaliangas, T.; Manolopoulou, S.; Dimopoulos, T. Physical and mechanical properties of chemically grouted sand. Tunn. Undergr. Space Technol. 2011, 26, 718-724. [CrossRef]

24. Chen, L.; Lin, D.F. Stabilization treatment of soft subgrade soil by sewage sludge ash and cement. J. Hazard. Mater. 2009, 162, 321-327. [CrossRef]

25. Wu, J.; Deng, Y.; Zheng, X.; Cui, Y.; Zhao, Z.; Chen, Y.; Zha, F. Hydraulic conductivity and strength of foamed cement-stabilized marine clay. Constr. Build. Mater. 2019, 222, 688-698. [CrossRef]

26. Wu, J.; Liu, L.; Deng, Y.F.; Zhang, G.P.; Zhou, A.; Wang, Q. Distinguishing the effects of cementation versus density on the mechanical behavior of cement-based stabilized clays. Constr. Build. Mater. 2021, 271, 121571. [CrossRef]

27. Jongpradist, P.; Youwai, S.; Jaturapitakkul, C. Effective void ratio for assessing the mechanical properties of cement-clay admixtures at high water content. J. Geotech. Geoenviron. Eng. ASCE 2011, 1376, 621-627. [CrossRef]

28. Ge, L.; Wang, C.C.; Hung, C.W.; Liao, W.C.; Zhao, H. Assessment of strength development of slag cement stabilized kaolinite. Constr. Build. Mater. 2018, 184, 492-501. [CrossRef]

29. Nayak, S.; Sarvade, P.G. Effect of cement and quarry dust on shear strength and hydraulic characteristics of Lithomargic clay. Geotech. Geol. Eng. 2012, 30, 419-430. [CrossRef]

30. Lin, D.F.; Luo, H.L.; Hsiao, D.H.; Chen, C.T. Enhancing soft subgrade soil with a sewage sludge ash/cement mixture and nano-silicon dioxide. Environ. Earth Sci. 2016, 75, 619. [CrossRef]

31. Benson, C.H.; Daniel, D.E. The influence of clods on the hydraulic conductivity of a compacted clay Geotech. J. Geotech. Eng. 1989, 1168, 1231-1248. [CrossRef]

32. Monkul, M.M.; Etminan, E.; Şenol, A. Influence of coefficient of uniformity and base sand gradation on static liquefaction of loose sands with silt. Soil Dyn. Earthq. Eng. 2016, 89, 185-197. [CrossRef]

33. Daniel, D.E.; Benson, C.H. Water content-density criteria for compacted soil liners. J. Geotech. Eng. ASCE 1990, 11612, 1811-1830. [CrossRef]

34. Das, B.M.; Sobhan, K. Principles of Soil Mechanics and Foundation Engineering; Cengage Learning: Singapore, 2017.

35. Holtz, R.D.; Kovacs, W.D.; Sheaahan, T.C. An Introduction to Geotechnical Engineering, 2nd ed.; Pearson: Upper Saddle River, NJ, USA, 2011.

36. Yoobanpot, N.; Jamsawang, P.; Horpibulsuk, S. Strength behavior and microstructural characteristics of soft clay stabilized with cement kiln dust and fly ash residue. Appl. Clay Sci. 2017, 141, 146-156. [CrossRef]

37. Chen, Y.G.; Zhua, C.M.; Ye, W.M.; Cui, Y.J.; Chen, B. 2016 Effects of solution concentration and vertical stress on the swelling behavior of compacted GMZ01 bentonite. Appl. Clay Sci. 2017, 124-125, 11-20. [CrossRef]

38. Emmanuel, E.; Anggraini, V. Effects of desiccation-induced cracking and leachate infiltration on the hydraulic conductivity of natural and olivine-treated marine clay. Int. J. Environ. Sci. Technol. 2020, 17, 2259-2278. [CrossRef]

39. Kalkan, E. Influence of silica fume on the desiccation cracks of compacted clayey soils. Appl. Clay Sci. 2009, 43, 296-302. [CrossRef]

40. Sheu, C.; Lin, T.T.; Chang, J.E.; Cheng, C.H. The feasibility of mudstone material as a natural landfill liner. J. Hazard. Mater. 1998, 58, 237-247. [CrossRef]

41. Hsiao, D.H.; Lin, Y.C. A Study of Mudstone in Taiwan as a Landfill Material. In Proceedings of the 2004 Taiwan Rock Engineering Symposium, Tamsui, Taiwan, 21-22 October 2004; pp. 678-685.

42. Ray, H.M.T.; Yanful, E.K.; Fakher, A. Desiccation-induced cracking and its effect on the hydraulic conductivity of clayey soils from Iran. Can. Geotech. J. 2007, 44, 276-283. [CrossRef]

43. Horpibulsuk, S.; Miura, N.; Nagaraj, T.S. Clay-water/cement ratio identity for cement admixed soft clays. J. Geotech. Geoenviron. Eng. ASCE 2005, 1312, 187-192. [CrossRef]

44. Horpibulsuk, S.; Suddeepong, A.; Chinkulkijniwat, A.; Liu, M.D. Strength and compressibility of lightweight cemented clays. Appl. Clay Sci. 2012, 69, 11-21. [CrossRef] 
45. ASTM. Standard Practice for Classification of Soils for Engineering Purposes; American Society for Testing and Materials: Conshohocken, PA, USA. Available online: https://www.globalspec.com/supplier/profile/ASTMInternational (accessed on 19 March 2019).

46. Takahashi, H.; Morikawa, Y.; Fujii, N.; Kitazume, M. Thirty-seven-year investigation of quicklime-treated soil produced by deep mixing method. Ground Improv. 2018, 1713, 135-147. [CrossRef]

47. Chen, M.; Wena, P.; Wang, C.; Chai, Z.; Gao, Z. Evaluation of particle size distribution and mechanical properties of mineral waste slag as filling material. Constr. Build. Mater. 2020, 253, 119183. [CrossRef]

48. Das, B.M. Principles of Geotechnical Engineering, SI Edition, 7th ed.; Cengage Learning: Stamford, USA, 2010.

49. Fredlund, D.G.; Rahardjo, H. Soil Mechanics for Unsaturated Soils; John Wiley \& Sons INC.: Hoboken, NJ, USA, 1993.

50. Zeng, L.L.; Hong, Z.S.; Cui, Y.J. Determining the virgin compression lines of remolded clays at different initial water contents. Can. Geotech. J. 2015, 52, 1408-1415. [CrossRef] 